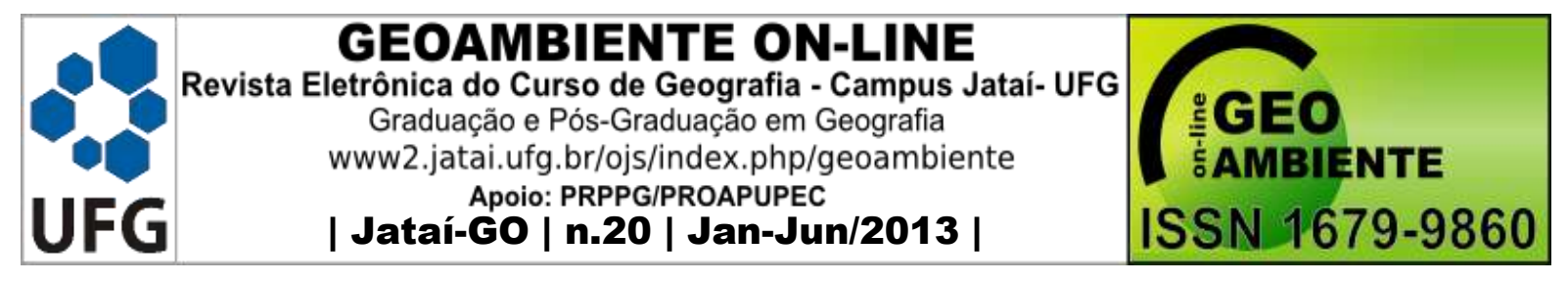

\title{
ANÁliSE dAS POLÍTICAS PÚBLICAS PARA CRIAÇÃO DE ASSENTAMENTOS RURAIS NO TRIÂNGULO MINEIRO/ ALTO PARANAÍBA
}

Danielle Fabiane Silva

(Universidade Federa de Uberlândia, danigeo_fabiane@ hotmail.com)

\section{Resumo}

O presente trabalho analisa a influência do processo da territorialização da Reforma Agrária de Mercado - RAM em Minas Gerais, sobretudo na mesorregião do Triângulo Mineiro/ Alto Paranaíba a partir da implantação do Projeto Banco da Terra. Propõe ainda, classificar as tipologias de criação de assentamentos rurais no estado, assim como os desdobramentos da RAM que culminaram com a criação do Movimento dos Atingidos pela Reforma Agrária de Mercado - MARAM, com o objetivo de enfrentar os problemas de insolvência da dívida dos agricultores nos empreendimentos de Reforma Agrária de Mercado, a partir de ações coletivas entre os assentados e entidades como a Animação da Pastoral Rural (APR) e a Ação Franciscana de Ecologia e Solidariedade (AFES).

Palavras chave: Assentamentos Rurais, Reforma Agrária de Mercado e Movimento dos Atingidos pela Reforma Agrária de Mercado.

\section{Abstract:}

\section{ANALYSIS OF PUBLIC POLICY FOR CREATION OF RURAL SETTLEMENTS IN TRIÂNGULO MINEIRO/ ALTO PARANAÍBA}

This paper analyzes the influence of the process of the territorialisation of Agrarian Reform Market - RAM in Minas Gerais, especially in the middle region of the Triangulo Mineiro / Alto Paranaíba from the implementation of the Project Land Bank. It also proposes, sort of creating typologies of rural settlements in the state, as well as the unfolding of RAM that led to the creation of the Movement of People Affected by the Agrarian Reform of the Market -

\footnotetext{
Artigo recebido para publicação em 09 de Janeiro de 2013 


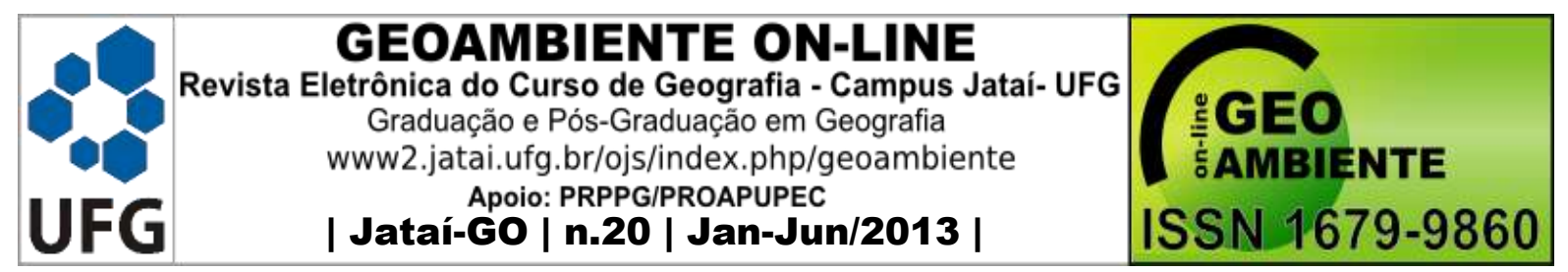

Maram, in order to address the debt problems of insolvency of farmers developments of the Agrarian Reform of Market, from collective action among the settlers and organizations like the Rural Pastoral Animation (PRA) and the Franciscan Ecology Action and Solidarity (AFES).

Keywords: Rural Settlements, Land Reform of Market and Movement of People Affected by the Land Reform Market.

\section{Resumen}

\section{ANÁLISIS DE POLÍTICAS PÚBLICAS PARA LA CREACIÓN DE ASENTAMIENTOS RURALES EN TRIÁNGULO MINERO / ALTO PARANAÍBA}

Este trabajo analiza la influencia del proceso de la territorialización de mercado de la Reforma Agraria - RAM en Minas Gerais, especialmente en la región centro del Triángulo Mineiro / Alto Paranaíba de la implementación del Banco de Tierras del Proyecto. Asimismo, se propone, una especie de creación de tipologías de asentamientos rurales en el estado, así como el despliegue de RAM que llevó a la creación del Movimiento de Afectados por la Reforma Agraria de Mercado - Maram, con el fin de abordar los problemas de la deuda de la insolvencia de los agricultores la evolución de la Reforma Agraria de Mercado, a partir de la acción colectiva entre los colonos y organizaciones como la Pastoral de animación Rural (ARP) y la Acción Ecología franciscana y la Solidaridad (AFES).

Palabras clave: Los Asentamientos Rurales, la Reforma Agraria de Mercado y El Movimiento del Mercado de Afectados por la Reforma Agraria de Mercado.

\section{Introdução}

O presente trabalho apresenta reflexões sobre Reforma Agrária de Mercado - RAM a partir de duas pesquisas realizadas em nível de Extensão: "Da prisão da dívida ao território da política: o Movimento dos Atingidos pela Reforma Agrária de Mercado - MARAM conhecimento e direitos sociais" e "Agricultura Familiar como base para o desenvolvimento territorial local e sustentável: avaliando experiências de projetos de Reforma Agrária no 


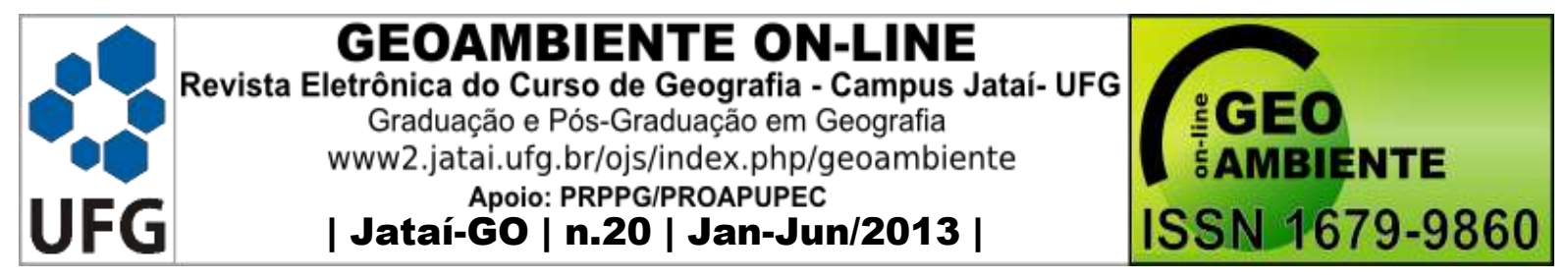

Triângulo Mineiro" nos anos de 2009-2010, com o apoio da Pró-Reitoria de Extensão, Cultura e Assuntos Estudantis, da Universidade Federal de Uberlândia ${ }^{1}$.

O primeiro projeto buscou contribuir para o fortalecimento dos agricultores diante da atual conjuntura da Reforma Agrária de Mercado, por meio da criação de uma cartilha informativa e o segundo veio ao encontro à necessidade de ampliar os resultados encontrados por meio de um material que visasse à capacitação dos seus dirigentes para lidar com os trâmites jurídicos e burocráticos desse tipo de política agrária.

A Reforma Agrária de Mercado - RAM iniciou-se com os incentivos e recursos do Banco Mundial durante o primeiro mandato do presidente Fernando Henrique Cardoso (19951998), com a criação do programa Cédula da Terra (1996), posteriormente denominado de Banco da Terra (1998), criado com a finalidade de combater a pobreza no campo e realizar a Reforma Agrária no país. O programa se manteve durante os dois mandatos consecutivos do presidente Luis Inácio Lula da Silva (2003-2010), porém com nome e público-alvo distintos para filhos de assentados ou descendentes diretos de negros e índios, mas ainda com o mesmo objetivo de satisfazer as necessidades do pequeno produtor rural.

Inicialmente, os principais estados que aderiram a essa forma de acesso a terra foram aqueles que apresentam um elevado índice de pobreza no campo, como Maranhão, Ceará, Pernambuco, Bahia e o norte de Minas Gerais. Atualmente a RAM está inserida em 21 estados da federação, no entanto, em Minas Gerais os projetos estão concentrados em determinadas mesorregiões como o Sul de Minas e a Zona da Mata, áreas em que a luta pela terra se faz moderada. Assim como nas demais regiões do país, em Minas Gerais a implantação dos projetos RAM não ocorreu de forma diferente e a criação de assentamentos rurais tem levado a um processo de insolvência e endividamento, comprometendo assim as atividades produtivas e a reprodução social das famílias de agricultores.

O procedimento metodológico empregado consistiu em leituras sobre a temática e a análise de documentação dos beneficiários (contratos assinados pelos agricultores assentados) nos municípios da mesorregião do Triângulo Mineiro, disponíveis na Animação da Pastoral Rural (APR) e a Ação Franciscana de Ecologia e Solidariedade (AFES). A partir desse material, foi possível conhecer as principais associações envolvidas no processo, a tipologia dos assentamentos e o valor pago por essas propriedades, entre 1998 e 2009, período que 


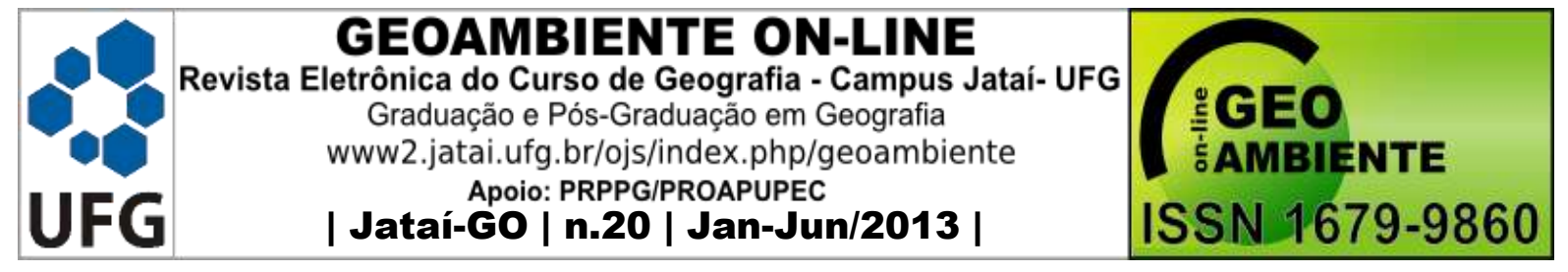

marca a criação do primeiro assentamento RAM e último Relatório do Banco de Dados da Luta pela Terra - DATALUTA, categoria assentamentos.

A categoria assentamentos rurais do Dataluta possui dados disponíveis desde 1969, advindos de fontes como o Instituto Nacional de Colonização e Reforma Agrária (INCRA) e da Associação Nacional de Órgãos Estaduais de Terra (ANOTER). Durante a sistematização dos dados, além do registro e da exclusão de duplicação de informações, os assentamentos são classificados de acordo com o nome, número de famílias, ano de origem, fonte e tipo. Estes dados demonstram que em Minas Gerais, a RAM ocorreu em áreas onde a luta pela terra (manifestações, ocupações e acampamentos) tem atuação menos expressiva, de acordo com as particularidades do processo histórico, além de diferentes situações sociais e culturais de cada mesorregião geográfica.

A pesquisa também avalia o contexto sociopolítico deste tipo de reforma agrária, que culminou em 2005 com a criação do Movimento dos Atingidos pela Reforma Agrária de Mercado - MARAM na região do Triângulo Mineiro, movimento específico que foi criado com o objetivo de enfrentar os problemas de insolvência da dívida dos agricultores nos assentamentos, a partir de ações coletivas entre os assentados e entidades como a Animação da Pastoral Rural (APR) e a Ação Franciscana de Ecologia e Solidariedade (AFES). Ao longo de sua trajetória, MARAM tem conquistado algumas vitórias, como a renegociação das dívidas e a individualização dos lotes através de medidas provisórias e particularizando como único movimento de luta na problemática da Reforma Agrária de Mercado no Brasil.

\section{Discussões e resultados}

\subsection{As políticas de Reforma Agrária no Brasil}

No Brasil, as políticas públicas para as desapropriações de terras tem sido a principal via para a implantação de assentamentos rurais, uma vez que historicamente o país não desenvolveu outras formas de acesso para uma reforma agrária efetiva. Diante de tal conjuntura, as elites e oligarquias rurais fortalecem o processo de exclusão, expropriando milhões de famílias sem terra e de pequenos agricultores.

Apenas desapropriações de terras em pontos de maior tensão para amansar os trabalhadores rurais e, eventualmente, desapropriações em áreas em que isso for de 


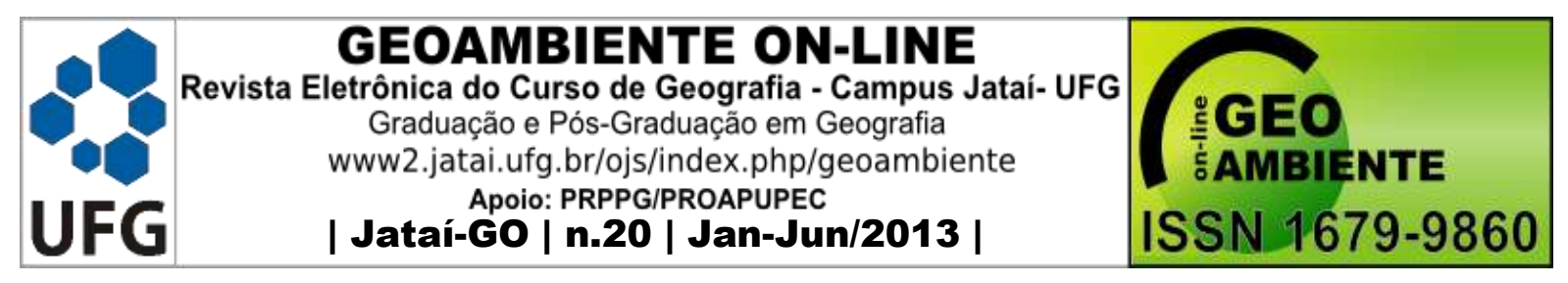

interesse dos proprietários. É muito pouco provável que um regime político amplamente apoiado e dominado pelas oligarquias rurais, pelos grandes proprietários, ponha a mão para valer no direito de propriedade [...] (MARTINS, 1986, p. 52).

Somado a este processo, durante as décadas de 1960 e 1970, o Governo Militar desenvolveu medidas voltadas somente para questões de cunho produtivas, marginalizando o lado social. Tal fato condicionou a concentração fundiária e a modernização agrícola, incentivada por medidas governamentais como a "modernização conservadora", fortaleceram investimentos no agronegócio. Devido ao cunho ideológico socialista presente nos movimentos de luta e dos partidos políticos atuantes da época, as políticas públicas para a Reforma Agrária praticamente não foram atendidas, pois havia por parte do governo o temor em apoiá-las. Contudo, formam criadas algumas ações para conter as reivindicações dos movimentos sociais pré-ditadura, como a promulgação do Estatuto da Terra (1964).

Além do Estatuto da Terra, foi criado também o Instituto Brasileiro de Reforma Agrária- IBRA, órgão que veio a ser o Instituto Nacional de Reforma Agrária - INCRA. Cabia ao IBRA executar as seguintes providências: (ESTATUTO DA TERRA, 1964).

a) Realizar o cadastro e zoneamento das propriedades rurais;

b) $\mathrm{O}$ direito de desapropriar as propriedades que não cumprem com suas funções sociais e classificadas como latifúndio;

c) A classificação das terras, formas e condições de uso atual e potencial da propriedade, e seleção dos candidatos à aquisição das parcelas;

d) A possibilidade de formação de cooperativas em propriedades de terras já reformadas;

No entanto, a implantação de um projeto progressista em pleno regime militar confirmou um verdadeiro conflito entre as classes dominantes da época. Tem-se na prática, a implantação de uma política produtivista e, no campo da sociedade política o acirramento da disputa pela reforma agrária.

Para Graziano da Silva (1982), o Estatuto da Terra teve como especificidade o fato de ter duas estratégias distintas: uma claramente "distributivista", voltada para a democratização da propriedade da terra e outra concentradora, já sinalizando a opção que prevaleceria nos anos seguintes a 1970, com a chamada "modernização conservadora". 


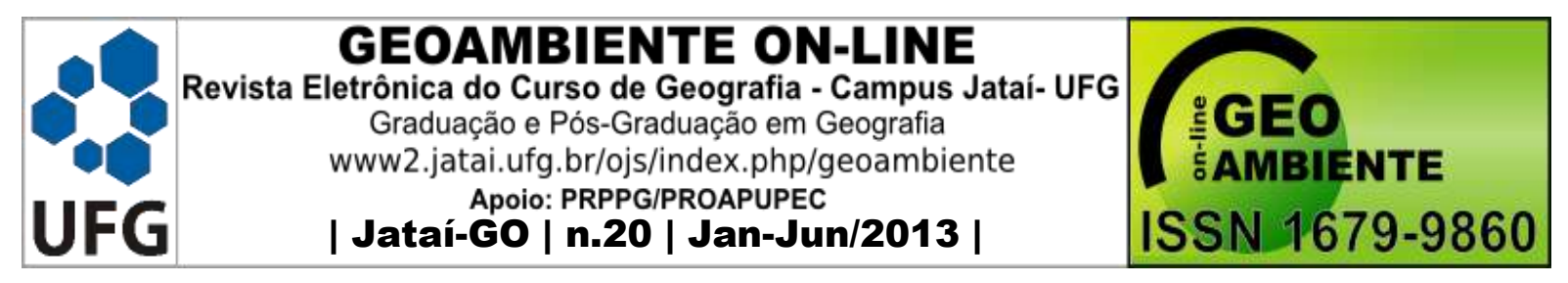

A "modernização conservadora" foram créditos cedidos pelo Estado voltados para promover o desenvolvimento agrícola no Brasil. Contudo, durante sua implantação, os créditos foram direcionados principalmente para as grandes propriedades, o que para Graziano da Silva (1982), favoreceu a concentração de terras, o fortalecimento do agronegócio e a expansão da pecuária para a Amazônia.

A segunda metade da década de 1980 se iniciava com o fim do regime militar e ainda carregava consigo as cicatrizes da ditadura militar. Havia uma verdadeira crise da modernização conservadora, os movimentos sociais permaneciam rechaçados pela mídia e pelo governo, fato que provocou o aumento da concentração fundiária e da violência no campo por falta de diretrizes para a Reforma Agrária, o que para Gomes (2002), se justifica pois,

\begin{abstract}
O poder executivo tinha como base de sustentação do governo a bancada que votou contra a reforma agrária constituinte; o poder legislativo contava com uma forte presença de proprietários de terra, inclusive do presidente da UDR (União Democrática Ruralista); o poder judiciário sofria de forte carência em formação em Direito Agrário além de estar tradicionalmente ligado ao conservadorismo e ao poder local; as forças militares apesar de distintas agora da questão agrária mentiam seu posicionamento de guardiã da segurança e da propriedade privada e do processo fundiário; grande parte da imprensa e dos meios de comunicação era ligada a grupos econômicos com fortes interesses fundiários, mantendo uma nítida postura conservadora (GOMES, 2002, p.33).
\end{abstract}

Em 1985, ao assumir a presidência da república após a morte do Presidente Tancredo Neves, o vice- presidente José Sarney retomou algumas medidas a favor da reforma agrária, dentre elas várias emendas e novos ministérios, entre eles o Ministério da Reforma e do Desenvolvimento Agrário - MIRAD, ao qual passou a subordinar-se ao Instituto Nacional de Colonização e Reforma Agrária - INCRA.

Baseado no Estatuto da Terra, que em sua essência, determinava a redemocratização da distribuição de terras, nesse momento criado o Primeiro Plano Nacional de Reforma Agrária da Nova República - PNRA em 1985.

Para a implantação das medidas, o plano contava com metas a serem cumpridas a longo, médio e curto prazo e a extensão das áreas a serem desapropriadas e número de famílias a serem assentadas, seriam selecionadas de acordo com as zonas prioritárias de Reforma Agrária do país. 


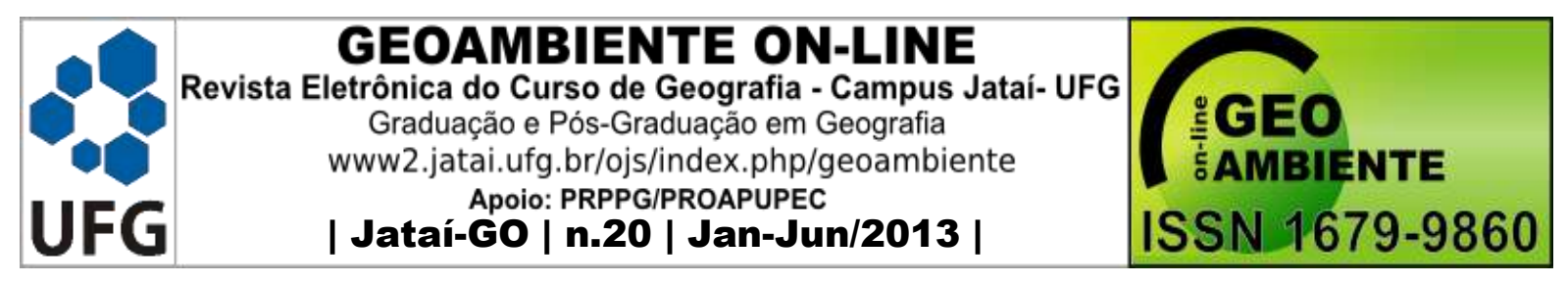

O PNRA buscava, a principio, atender às demandas sociais mais urgentes no âmbito rural, visando a desapropriação que permitissem o assentamento de trabalhadores sem terra nas áreas de maior potencial de conflito do país, sobretudo no Norte - Pará e Maranhão - e o Nordeste. Sintomaticamente, no entanto, os mais virulentos ataques ao PNRA partiram - para surpresa de seus idealizadores - não de latifundiários "tradicionais", mas justamente de São Paulo, capitaneando outros Estados “desenvolvidos” do Sul e Sudeste (STÉDILE, 2005, p. 92).

Dessa forma, a União Democrática Ruralista - UDR líder em representação política dos latifundiários passou a atuar contra o projeto por meio da violência no campo. Diante das pressões contrárias da oposição e a desfiguração que sofreu, o PNRA foi inviabilizado, iniciando um longo processo de trocas de ministros e presidentes do INCRA, de modo que os ruralistas mantiveram o controle do PNRA até seu o enterro completo, em 1990, com a eleição do governo Collor (FERNANDES, 1999, p.184). Assim, mesmo com a transição de um governo ditatorial para um governo democrático, ainda havia repressões e forças contrárias a Reforma Agrária. Da proposta inicial de assentar 1 milhão e 400 mil famílias, apenas 67.158 foram atendidas, ou seja, "o número de beneficiários de projetos de Reforma Agrária no final do governo Sarney (1990) não atingiu 10\% da meta inicial” (RANIERI, 2003, p. 13).

Em 1989, a reforma agrária saiu da pauta política do governo federal, com a eleição de Fernando Collor, árduo defensor dos latifundiários. O governo Collor (1990-1992) foi pautado por um total desmonte do aparato público nesse e em diversos setores da estrutura administrativa. O MIRAD foi extinto e o INCRA e outros órgãos públicos também entraram em conflito, o que resultou em nenhuma desapropriação por interesse social para fins de reforma agrária. Assim, a UDR praticamente assumiu o controle da "Reforma Agrária" no Brasil.

O ministro Antonio Cabrera Mano assumiu o Ministério da Agricultura e promoveu o abandono completo da Reforma Agrária. A realização de assentamentos e a arrecadação de terras praticamente limitaram-se a concluir os processos iniciados na gestão anterior. Além disso, foi lançado o Programa da Terra, tendo como um dos vértices a inclusão do Exército na tomada de decisões e aplicação de medidas no tema, bem como a criação das bolsas de arrendamento e a aquisição de terra mediante compra para fins de reforma agrária.

Iniciou-se o período de repressão e perseguição aos movimentos sociais, sobretudo ao MST e uma intensificação da violência no campo. As ocupações eram rechaçadas pela 


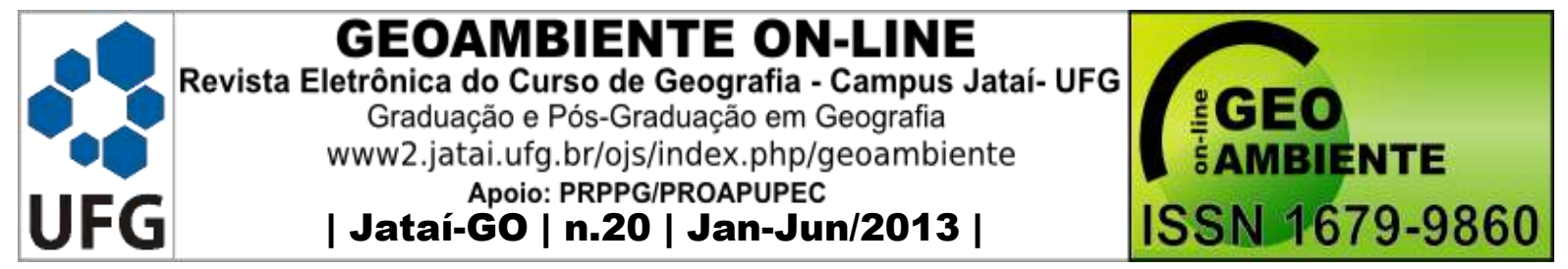

polícia, de modo que em 1990, diminuíram significativamente os números de ocupações e de famílias na luta pela terra. Começaram as mais fortes repressões contra os sem-terra, que não se limitavam nas ações da força policial, e se valiam também da intervenção do Poder Judiciário como uma nova cerca para impedir as ocupações, por meio da criminalização ações das famílias sem-terra.

A queda de Collor e a ascensão de Itamar Franco (1992) em pouco alterou a estrutura agrária e o processo de reforma agrária. A partir deste período as políticas de desenvolvimento do campo regulamentadas pela Constituição Federal de 1988, deram espaço a políticas neoliberais privilegiando a esfera financeira e não de Reforma Agrária, como as leis $\mathrm{N}^{\circ}$ 8.629, mais conhecida como a Lei Agrária e a Lei complementar 76 ou Lei do Rito Sumário. A primeira estabelecia o poder a União em desapropriar as propriedades rurais que não estejam cumprindo sua função social. Já a segunda confirma o procedimento de desapropriação de imóveis rurais por interesse social para fins de reforma agrária, por ações de rito sumário, ou seja, sentenças que não permitem recursos.

Este processo perdurou durante a década de 1990, no entanto essas leis foram modificadas em alguns aspectos pelas Medidas Provisórias editadas entre meados de 1997. Os setores que prestavam assistência e apoio aos agricultores foram privatizados e as políticas de reforma agrária foram substituídas por políticas de redistribuição de terras orientadas pelo mercado, o que intensificou os conflitos no campo e a expropriação dos pequenos proprietários.

\subsubsection{O governo Fernando Henrique Cardoso e a implantação da Reforma Agrária de} Mercado

Em 1994 Fernando Henrique Cardoso assumiu a presidência da república tendo a reforma agrária como prioridade em seu plano de ação. Somente no primeiro mandato foram criados os programas de apoio PROCERA (Programa de Crédito Especial para Reforma Agrária); Projeto LUMIAR; Projeto EMANCIPAR, do BID (Banco de Interamericano de Desenvolvimento) e os projetos desenvolvidos com o apoio do Banco Mundial, como o Cédula da Terra (GOMES, 2002, p.44). 


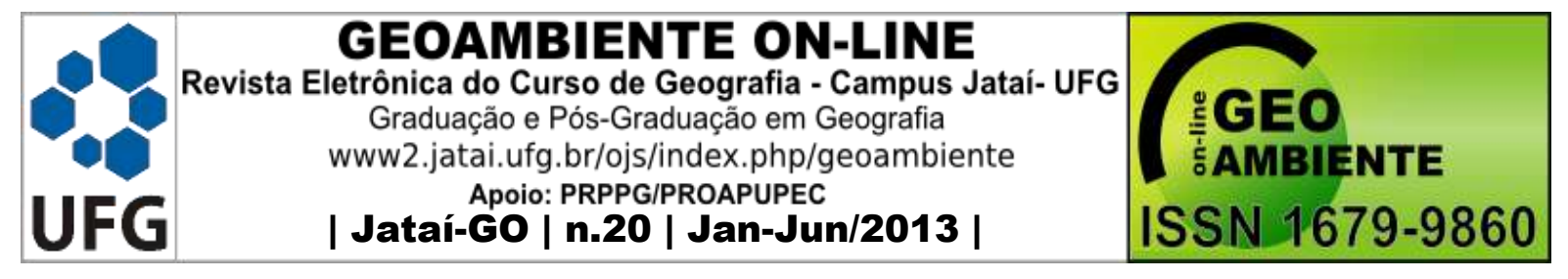

No entanto, havia neste momento, a suposição de que o Brasil já não era um país agrícola, que o número de trabalhadores rurais era proporcionalmente pequeno e caminhava ainda para maior redução, seguindo a tendência moderna dos países desenvolvidos. Dessa forma, apresentava-se um descompasso entre o Brasil moderno dos projetos nacionais de desenvolvimento. Logo, para muitos, a pequena agricultura ou agricultura familiar, tidas como [...] "agrícolas atrasadas, de baixa produtividade, representava uma modalidade de economia destituída de empreendedorismo e de futuro. Algo a não ser estimulado nem apoiado" (MARTINS, 2003.p.144).

As políticas públicas e os investimentos públicos implementados garantiram apenas a ampliação do agronegócio e do mercado de terras. Tais medidas neoliberais eram direcionadas tendo como objetivo a produção para o mercado externo, o que resultou no aprofundamento da subordinação da economia brasileira aos interesses dos países ricos e grandes empresas transnacionais que monopolizaram o setor de produção de insumos e o comércio de produtos nesse setor.

Para Teixeira (1997), a política econômica do Governo Fernando Henrique priorizou a grande produção em detrimento agricultura familiar, como a criação de novas regras bancárias no direcionamento de crédito para o grande produtor e aos produtos de exportação. Houve também a transferência de recursos públicos que sustentavam operações amparadas pela política de preços mínimos para acordos fora de alcance dos pequenos produtores.

Frente a esses acontecimentos, os movimentos sociais e entidades organizadas como a Igreja Católica se mostraram insatisfeitos com o não cumprimento das metas de campanha. Dessa forma, as ocupações de terra se intensificaram como forma de pressionar o governo para a criação de medidas voltadas para a agricultura familiar, conforme demonstra os dados apresentados no gráfico 1 .

Como resultado, o governo ampliou as áreas de assentamentos e criou três programas para garantir a permanência da agricultura familiar, o Programa Nacional de Fortalecimento da Agricultura Familiar - PRONAF, o Programa Geração de Emprego e Renda Rural - PROGER RURAL e a Previdência Rural.

No entanto, essas ações não passaram de medidas compensatórias que visavam apenas reduzir as diferentes formas de luta dos movimentos sociais, e ainda, foi atestado que o 


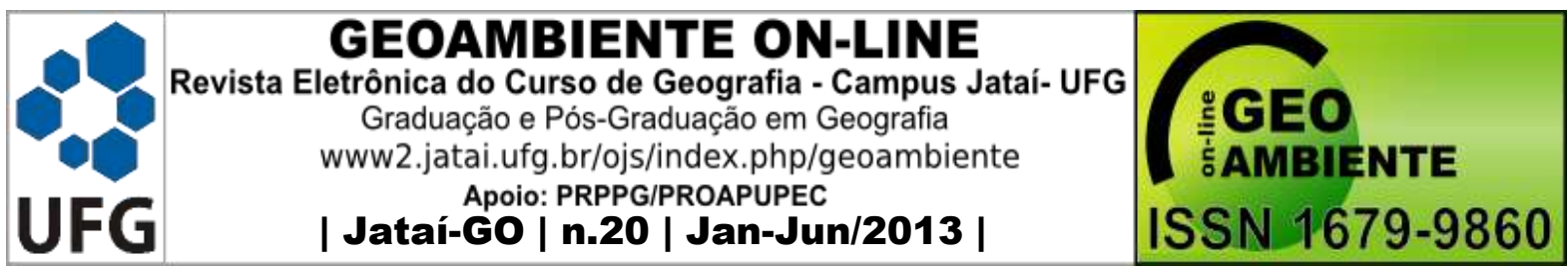

financiamento era destinado apenas aos produtores ligados às empresas agroindustriais ou cooperativas por elas ministradas. Para Fernandes (2001),

Essas políticas têm o capital e o mercado como principais referências, de modo que procura destituir de sentido as formas históricas de luta dos trabalhadores. A luta pela terra, que tem como princípio o enfrentamento ao capital, defronta-se com esse programa, por meio do qual pretende convencer os pequenos agricultores e os semterra a aceitarem uma política em que a integração ao capital seria a melhor forma de amenizar os efeitos da questão agrária (FERNANDES, 2001, p.21).

Gráfico 1 - Ocupações de terra por período governamental.

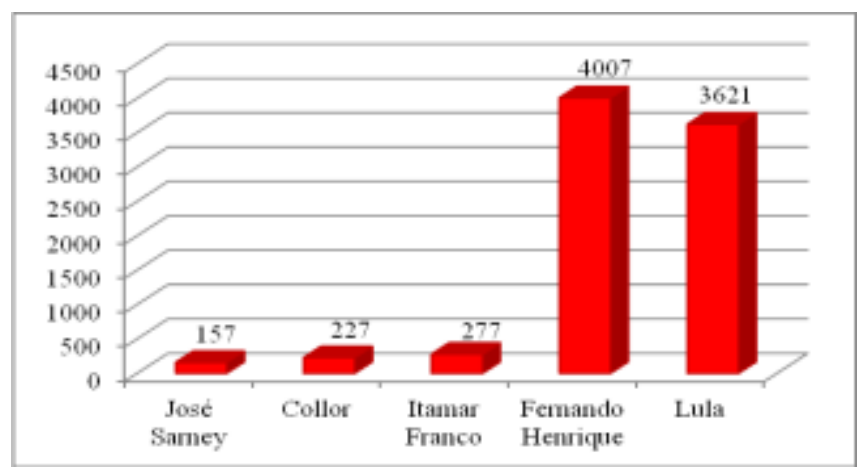

Fonte: Banco de Dados da Luta pela Terra - DATALUTA, 2010

Org.: SILVA, D.F./2011.

Mas, o que reforçou o descaso deste presidente para com a Reforma Agrária, sem dúvida, foi o apoio à intervenção do Banco Mundial, por meio da liberação de linhas de crédito para a compra de terras, dando início à chamada "Reforma Agrária de Mercado RAM” no Brasil.

Este acordo envolve empréstimos internacionais e o governo federal por meio do Fundo de Terras e da Reforma Agrária. Também é possível que o financiamento seja realizado pelo acordo feito diretamente entre os organismos internacionais e os governos estaduais. Neste caso, os recursos são advindos do próprio estado e parte dos pequenos produtores cujo pagamento se dá por dinheiro, produtos, equipamentos ou mão de obra.

A Reforma Agrária de Mercado teve como principal objetivo combater a pobreza no campo e descentralizar a posse da terra. Contudo, o que se percebe é apenas uma forma do capital promover a redistribuição deste bem, transformando-o em mercadoria. E ainda, 


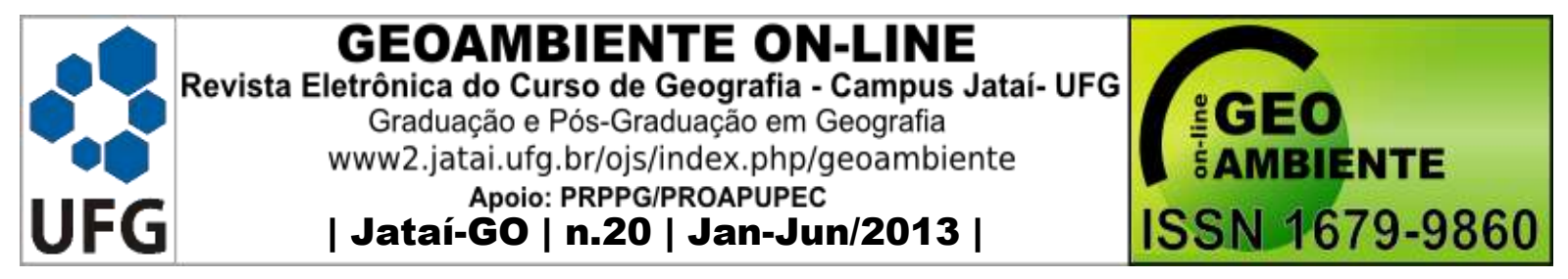

A criação de um dispositivo que permite a fragmentação do ejido e realização da mercantilização das parcelas de terras no mercado abre a condição necessária para que o capital promova uma espécie de assepsia do território, ou seja, elimine o campesinato e indígenas do território para liberar as possibilidades de livre domínio com vistas à implantação de megaprojetos de logística, agricultura capitalista, atividades industriais, etc. O capital, nem sempre promove ele próprio uma ofensiva direta aos camponeses e indígenas, mas com frequência utiliza-se do aparato de Estado para fazê-lo de acordo com seus interesses (RAMOS FILHO, 2010, p.15).

Dessa forma, com implantação da Reforma Agrária de Mercado - RAM as ocupações de terra perderiam o sentido. Na verdade, o que se apresentava era uma intencionalidade de eliminar os conflitos por terra sem a realização de um novo reordenamento do poder e do território.

O primeiro programa criado nos moldes da RAM foi o Projeto Piloto de Reforma Agrária e Alvio da Pobreza, mais conhecido como Cédula da Terra - PCT, cujo objetivo era produzir uma "experiência-piloto de um novo modelo de política fundiária, integrada ao mercado e sem depender do governo em todas as etapas do processo, principalmente, na execução, como ocorre hoje (BRASIL, s/n, 1997)".

De acordo com RAMOS FILHO (2010), no ano seguinte a implantação da proposta da RAM, os primeiros estados a introduzir o PCT foram: Maranhão, Ceará, Pernambuco, Bahia e Minas Gerais, somando uma área de 131.348 hectares para 5.552 famílias. Entretanto, os movimentos sociais de luta pela terra deram prosseguimento ao processo de espacialização para conquistar sua territorialização por meio das ocupações. Dessa forma, confirma-se a ineficácia da Reforma Agrária de Mercado para eliminar os conflitos no campo e firmar-se como forma substitutiva à reforma agrária. Hoje ela está inserida em vinte e um estados da Federação.

Em 1998, Fernando Henrique venceu novamente as eleições presidenciais. Diferentemente do primeiro mandato, que tinha a Reforma Agrária como meta, seu plano de governo baseou-se numa política agrária repressora, criminalizando as ações dos movimentos sociais e desenvolvendo uma política de mercantilização da terra. As políticas de Reforma Agrária permaneceram como políticas compensatórias, com a implantação de assentamentos rurais em áreas estratégicas, de acordo com a territorialização da luta pela terra.

Desse modo, em 2001, criou duas medidas provisórias: uma em que determinava o não assentamento das famílias que participassem das ocupações de terra e outra que 


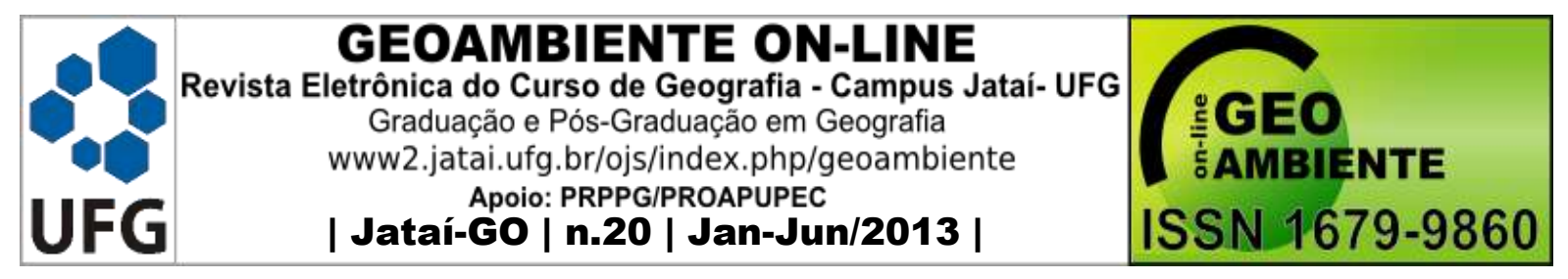

determinava a não vistoria das terras ocupadas por dois anos, quando ocupadas uma vez e por quatro anos quando ocupada mais de uma vez. Criou um cadastro nos Correios das famílias interessadas em serem beneficiadas pela política de assentamentos rurais. 839.715 famílias se cadastraram (FERNANDES, 2005, p.02).

Como resposta a este processo, a partir de 2001, houve um refluxo dos conflitos por terra e das diferentes formas de violência no campo, embora este tenha sido o terceiro período na média anual entre os anos de 1985 a 2009, como demonstra o gráfico 2.

Dessa forma, o governo FHC aprofundou a RAM ampliando o número de famílias, de estados beneficiados e institucionalizando-a, por meio da aprovação da lei complementar $n^{\circ}$ 93, de 04 de fevereiro de 1998, que instituiu o Fundo de Terras e da Reforma Agrária, mais conhecido como o Banco da Terra.

Os assentamentos criados por esse programa tiveram recursos advindos do Fundo de Terras e da Reforma Agrária e o Banco Nacional de Desenvolvimento Econômico e Social BNDES foi o órgão responsável pelo repasse do financiamento. As terras adquiridas foram incorporadas ao patrimônio da União e administradas pelo órgão gestor desse fundo. Os beneficiados teriam um prazo de até 20 anos para findar a dívida e, como no PCT, as famílias favorecidas teriam que se organizar em associações ou cooperativas e não possuir nenhum registro de atuação em ocupações de terras para o pleito do financiamento. Em quatro anos de atuação, o BT beneficiou 55 mil famílias, sendo que $46 \%$ delas decorrentes da região sul do país (CAMARGO, 2005, p.3).

Gráfico 2 - Média anual de conflitos por terra no Brasil - 1985 - 2009.

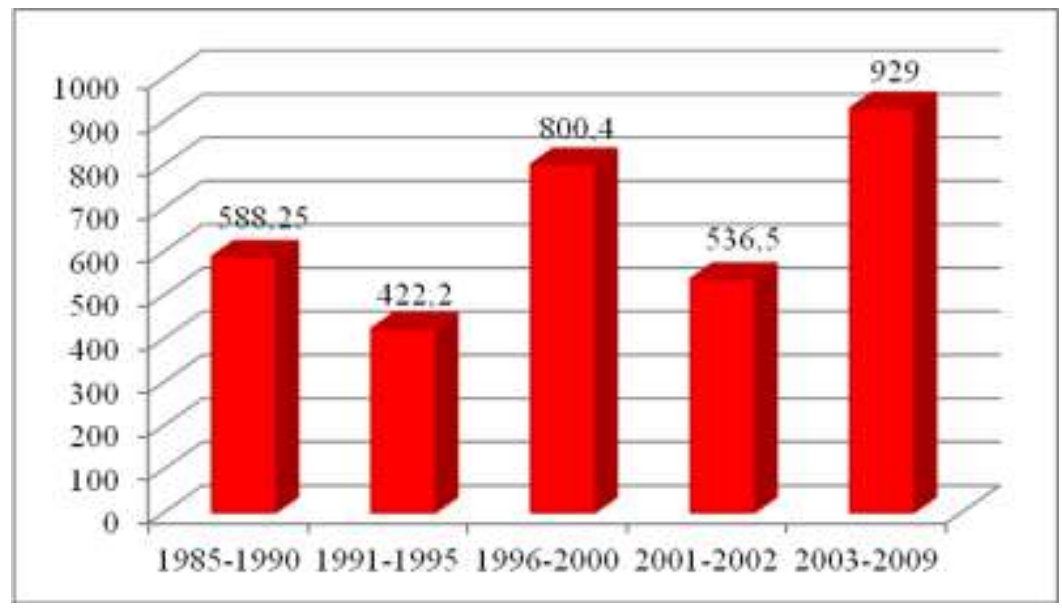

Fonte: GONÇALVES, C. W. P.; ALENTEJANO, P. R. R., 2011, p.108 


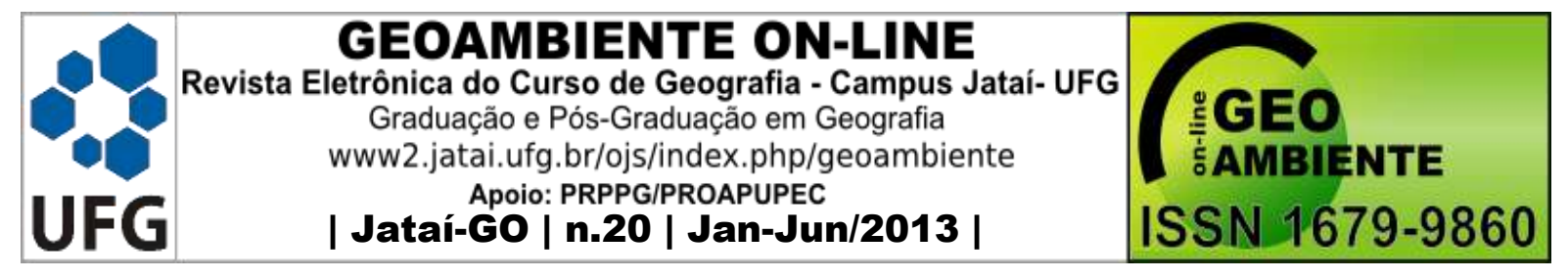

A partir de 2001, os projetos Cédula da Terra e Banco da Terra, já defasados, foram substituídos pelo programa denominado Crédito Fundiário, por meio de um novo acordo entre o Brasil e o Banco Mundial.

Neste projeto, o agricultor beneficiado recebe incentivos para a implementação de infraestruturas e de projetos produtivos, fato que não ocorria no projeto Banco da Terra. Contudo, o governo mudou as cláusulas de crédito, na tentativa de mostrar que a reforma agrária não dá certo, por meio da aceleração do processo de emancipação dos assentamentos, através da redução de requisitos (serviços topográficos realizados; existência de estradas; condições habitacionais satisfatórias) e a previsão de entrega aos beneficiários dos títulos de propriedade, com prazo de 20 anos para pagar a terra, com carência de 3 ??? e juros de $6 \%$ ao ano para os novos assentados, 15 anos, com carência de 2, e juros de $6 \%$ ao ano e para os mais antigos, 18 anos com 3 de carência para os criados entre 1995 e 1998.

De acordo com o Banco de Dados da Luta pela Terra - DATALUTA, somando os dois mandatos do governo FHC (1995 - 2002), foram implantados 4.308 assentamentos de Reforma Agrária e 3.431 empreendimentos de Reforma Agrária de Mercado.

A política agrária do período em questão se pautou na tentativa de fazer uma reforma agrária e ao mesmo tempo, manter os conflitos no campo, tendo sempre o Estado como mediador. As políticas da RAM e a Medida Provisória que impedia a vistoria de terras já ocupadas exemplificam essa conjuntura.

\subsubsection{As políticas neoliberais do Governo Lula}

Em 2003 Luiz Inácio Lula da Silva assumiu a presidência da república com o apoio de vários movimentos sociais, como o Movimento dos Trabalhadores Rurais Sem Terra (MST) e a Confederação Nacional dos Trabalhadores na Agricultura (Contag). Dentro do governo, essas minorias conseguiram assumir cargos importantes, como a presidência do Instituto Nacional de Colonização e Reforma Agrária (INCRA) e do Ministério de Desenvolvimento Agrário (MDA). Assim, a opinião pública e as entidades sociais aguardavam por uma mudança na estrutura agrária do país. Neste ano, houve primeira ruptura com as políticas agrária do governo FHC, marcada pela criação do II Plano Nacional de Reforma Agrária - 


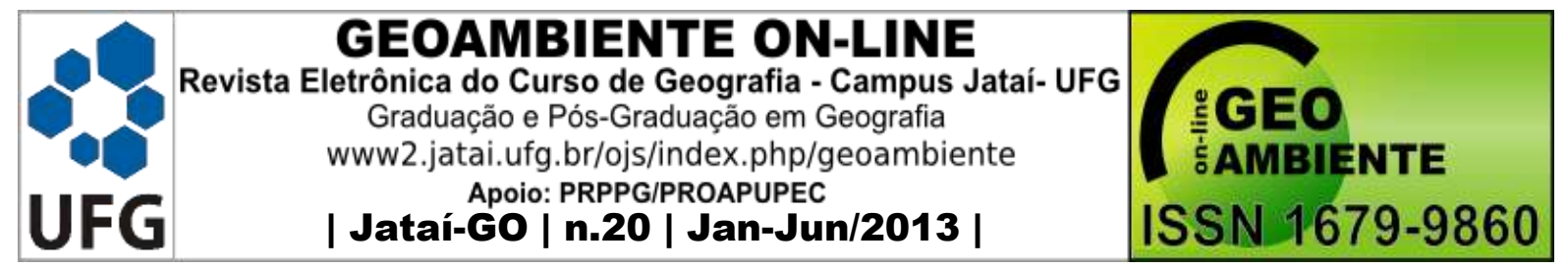

PNRA, embora não correspondessem todos os anseios dos movimentos e organizações camponesas.

O que diferenciava o II PRNA do anterior, implantado na década de 80, é que além da distribuição de terras, este mantinha em sua essência ações voltadas para saúde, educação, energia e saneamento, para que as famílias tenham condições de gerar renda e ter acesso aos seus direitos fundamentais.

Logo, concluímos que, enquanto o governo FHC baseou-se apenas em redistribuição de terras para conter as pressões sociais, o governo Lula reconheceu a importância dos movimentos e estabeleceu um diálogo entre a administração federal e os mesmos. Tal diplomacia aboliu a criminalização da luta pela terra e permitiu uma estabilização entre a reforma agrária constitucional e os programas neoliberais propostos pelo Banco Mundial. Porém, frente às pressões do setor ruralista, o documento foi reformulado, o que incitou novas mobilizações sociais para exigir o cumprimento das metas previstas no plano.

Após os dois mandatos, não houve muitas mudanças no cenário agrário nacional no que diz respeito à concentração fundiária. E ainda, os dados referentes aos números de assentamentos via Reforma Agrária criados nesse período foram inflados e,

"[...] tudo indica tratar-se de reconhecimento das famílias já assentadas para fins de sua inserção nas políticas do governo, mas nunca, novos assentamentos do governo LULA. São, portanto, casos típicos de reordenação de assentamentos antigos" (OLIVEIRA, 2006, p.8).

Outro entrave ao processo de reforma agrária é a origem das terras que descaracteriza o processo. Segundo o Ministério da Agricultura, do total de 400 mil famílias beneficiadas pelo II PNRA, $60 \%$ das terras foram adquiridas do próprio governo federal ou estadual e o restante de desapropriações (II PNRA, 2003 p. 19). Ou seja, o governo assentou mais famílias em terras públicas do que desapropriou terras dos latifúndios.

O II PNRA também contemplava ações para a RAM. Neste momento, foi instituído o Programa Nacional de Crédito Fundiário - PNCF, baseado nas políticas neoliberais do governo FHC, cuja meta era assentar 130 mil famílias via RAM, tendo como principio a concepção de alívio da pobreza rural e fortalecimento da agricultura familiar. O programa faz parte das ações da Secretaria de Reordenamento Agrário - SRA do Ministério do 


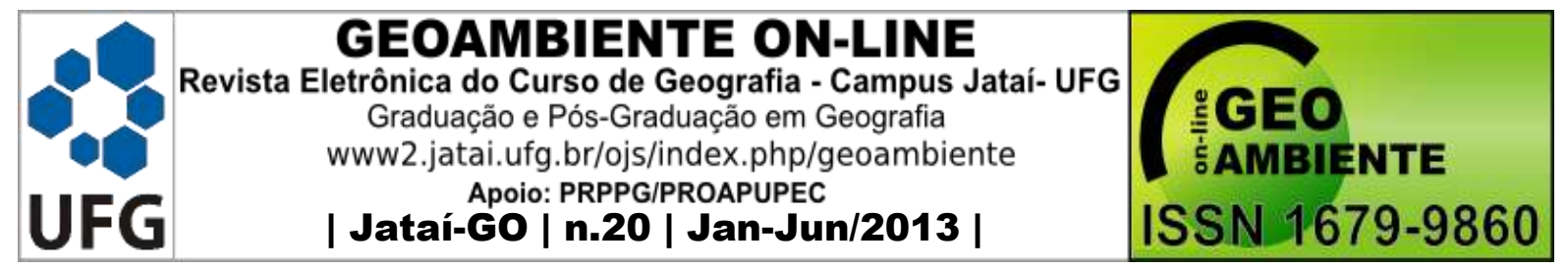

Desenvolvimento Agrário - MDA, tendo como recursos o Fundo de Terras, agora incorporado à política fundiária do Estado brasileiro e funcionando como um instrumento de longo prazo.

Novas linhas de financiamento da RAM foram criadas e cada uma delas com novas regras operacionais, mas como mesmo princípio do governo anterior. Em substituição ao PCT e ao $\mathrm{CF}$, foi criado o Combate à pobreza rural - CPR. Os beneficiários por esse projeto deveriam ser trabalhadores rurais sem terra ou pequenos produtores em estado de pobreza. $\mathrm{O}$ diferencial deste programa é que este consiste em oferecer o financiamento para a compra de terras e obras de infraestrutura. Os estados da região nordeste foram os mais contemplados por essa linha de crédito, embora ela também tenha se especializado nos demais estados.

Em substituição ao Banco da Terra, foi criado o programa Consolidação da Agricultura Familiar - CAF, cujo objetivo é atender famílias sem terra, pequenos produtores rurais ou ainda pequenas cooperativas cujos membros agreguem os grupos já citados. Os imóveis adquiridos para a criação desse tipo de assentamento devem ter uma infraestrutura básica e produtiva além de algumas benfeitorias. Embora esteja presente em todas as regiões brasileiras, inicialmente esta linha de financiamento foi designada para as regiões Sul e Sudeste.

Buscando ampliar o número de famílias beneficiadas, foi criado o projeto Nossa Primeira Terra/Consolidação da Agricultura Familiar, buscando atender jovens sem terra ou filhos de agricultores familiares na faixa etária entre 18 e 28 anos que almejam permanecer no campo, evitando assim o aumento do êxodo rural e a redução da concentração fundiária. Para tanto, os favorecidos do programa devem se organizar em associações para que o empréstimo seja executado.

Também foram criados os projetos Terra Negra Brasil - TNB e Terra para Liberdade TL, voltados para famílias afrodescendentes não quilombolas e trabalhadores resgatados de trabalho escravo, com a mesma lógica de financiamento da RAM.

Percebe-se então a intencionalidade destas políticas em capturar estes públicos, cuja potencialidade de organização social, via ocupações de terras, se faz mais expressiva diante da divisão ou perda de terras de seus pais e a falta de políticas públicas que cumpram suas responsabilidades sociais. 


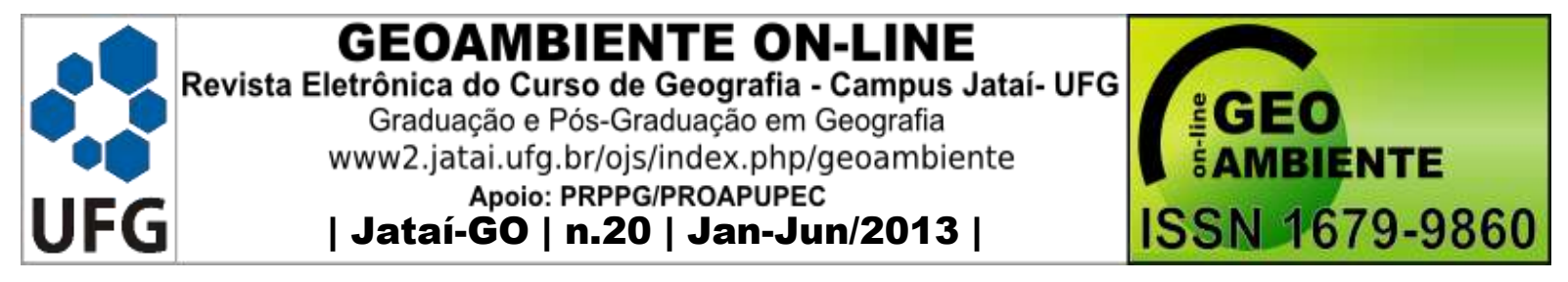

Muito além da perda de mobilização social, a RAM tem levado ao endividamento das famílias beneficiadas. Em geral, os mutuários não dispõe das condições para negociar a terra com os proprietários, por isso, na maioria dos casos a intermediação da compra e venda da terra são executadas pelos técnicos governamentais, a preços e juros acima da média do mercado.

\subsection{A territorialização da Reforma Agrária de Mercado - RAM em Minas Gerais e no} Triângulo Mineiro/ Alto Paranaíba.

Em Minas Gerais o órgão responsável pelo repasse das verbas federais, pelo acompanhamento e o controle dos projetos do Banco Mundial foi composto pela Secretaria de Estado e Regularização Fundiária - SEERF e pelo Instituto de Terras - ITER.

Os primeiros assentamentos de Reforma Agrária de Mercado no estado foram implantados pelo Programa Cédula da Terra em 1998, nas gestões do presidente Fernando Henrique Cardoso e o governador Eduardo Azeredo. A partir deste momento, a RAM ganhava prioridade para firmar o "sucesso" do financiamento de terras em detrimento às ocupações no campo.

Durante o segundo mandato do presidente FHC e Itamar Franco em Minas (1999 2002), o programa de Crédito Fundiário teve continuidade, com a introdução do projeto Banco da Terra no ano de 2000. Ao contrário do governo estadual anterior, a postura política do novo governador era de oposição às medidas neoliberais em curso, principalmente aquelas ligadas às privatizações estatais. Entretanto,

O governador Itamar decidiu atender a orientação do seu presidente do Instituto de Terras, sobre a intencionalidade deste programa em proteger os ruralistas do avanço da reforma agrária e dos impactos negativos já largamente conhecidos pelo Programa Cédula da Terra, fato que levou à promulgação do Decreto $N^{o} 41.344$ de 26 de outubro de 2000 (apenas um mês após a publicação do Decreto de criação do Conselho Gestor do Banco da Terra) que revoga o decreto anterior, o que na prática representa a interdição da operação do Programa Banco da Terra pelo governo estadual. Nesta perspectiva, não foi possível a construção de um ambiente político favorável à assinatura do convênio de parceria entre o Conselho Curador do Fundo de Terras e da Reforma Agrária - Banco da Terra e o governo de Minas Gerais. (RAMOS FILHO, 2010, p.79). 


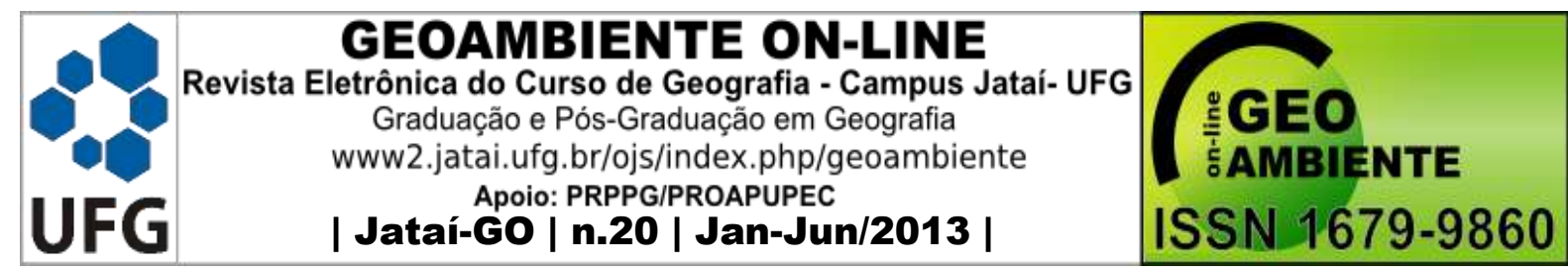

A consolidação da RAM no estado veio na administração do governador Aécio Neves e do presidente Luiz Inácio Lula da Silva (2003-2009) com a instituição e execução de outros programas de financiamento, como o Combate a Pobreza Rural - CPR e a Consolidação da Agricultura Familiar - CAF, fato que não ocorreu ao acaso. Temidos pelo processo de desvalorização de terras, alterações cambiais e queda no preço das commodities, os ruralistas mineiros buscaram soluções para conter os conflitos no campo e gerar novos negócios rentáveis, dentre as quais a manutenção da RAM no estado (RAMOS FILHO, 2010, p.79).

De acordo com o projeto Dataluta, somente em onze anos foram criados 572 empreendimentos, beneficiando 5.342 famílias. Por outro lado, foram implantados apenas 80 assentamentos de RA, fato que descreve a priorização da mercantilização da terra em oposição ao processo de reforma agrária, como demonstra a tabela 1.

Tabela 1 - Distribuição do número de famílias e Área de RA e RAM (1998-2009).

\begin{tabular}{cccccc}
\hline & Ano & \multicolumn{2}{c}{$\mathrm{N}^{\mathbf{c}}$ de Assentamentos } & \multicolumn{2}{c}{$\mathrm{N}^{\mathbf{c}}$ de Famílias } \\
& & RA & RAM & RA & RAM \\
\hline FHC - Eduardo Azeredo & 1998 & 9 & 19 & 481 & 765 \\
FHC - Itamar Franco & 1999 & 4 & 8 & 398 & 225 \\
& 2000 & 8 & 9 & 750 & 89 \\
& 2001 & 0 & 62 & 0 & 670 \\
Lula - Áecio Neves & 2002 & 4 & 101 & 246 & 1513 \\
& 2003 & 2 & 63 & 271 & 604 \\
& 2004 & 7 & 11 & 239 & 262 \\
& 2005 & 14 & 21 & 575 & 429 \\
& 2006 & 5 & 11 & 184 & 108 \\
& 2007 & 0 & 122 & 0 & 395 \\
TOTAL & 2008 & 5 & 143 & 132 & 241 \\
& 2009 & 22 & 2 & 761 & 41 \\
\hline
\end{tabular}

Fonte: Banco de Dados da Luta pela Terra - DATALUTA e Banco de Dados da Reforma Agrária de Mercado - BDRAM (2009); apud SILVA, D. F. (2011).

No entanto, concentração destas tipologias de assentamentos corresponde às características e atuação das políticas públicas de cada mesorregião e isso se deve aos diferentes processos históricos, econômicos, sociais, culturais e até mesmo físicos de cada mesorregião. Para compreender a consolidação deste processo, apresentamos a seguir as características das principais mesorregiões que representam esse cenário em Minas Gerais.

A mesorregião Norte de Minas possui características físicas e climáticas parecidas com o semi-árido nordestino, por isso, a Superintendência do Desenvolvimento do Nordeste 


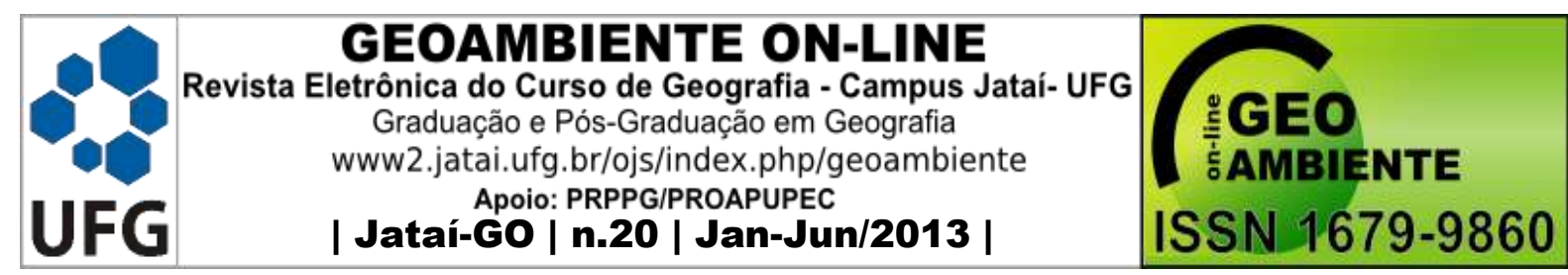

(SUDENE) passou a direcionar incentivos fiscais e linhas de crédito para o estabelecimento de empreendimentos comerciais, industriais e agropecuários. Tal medida atraiu grandes produtores de eucalipto e pinus destinados à produção de carvão vegetal. Assim, os pequenos agricultores frente à expulsão promovida pelos empreendimentos se organizaram, dando origem as primeiras formas de luta e a criação dos assentamentos de Reforma Agrária. Assim, a Reforma Agrária de Mercado que se apresenta de "forma pacifica" sem qualquer forma de luta é quase que inexistente. Este cenário permanece nos dias atuais, de acordo com o Dataluta, o Norte de Minas permanece em segundo lugar no número de ocupações de terras no estado, como demonstra a tabela 2 .

Tabela 2: Número de Ocupações por mesorregiões - (1990 - 2010).

\begin{tabular}{cccc}
\hline CLASS. & MESORREGIÕES & $\mathrm{N}^{\circ}$ DE OCUPAÇÕES & $\mathrm{N}^{\circ}$ DE FAMÍLIAS \\
\hline $1^{\circ}$ & Triângulo Mineiro/ Alto Paranaíba & 224 & 21888 \\
$2^{\circ}$ & Norte de Minas & 178 & 15240 \\
$3^{\circ}$ & Noroeste de Minas & 110 & 10610 \\
$4^{\circ}$ & Vale do Rio Doce & 46 & 6369 \\
$5^{\circ}$ & Jequitinhonha & 30 & 3382 \\
$6^{\circ}$ & Metropolitana de Belo Horizonte & 28 & 3453 \\
$7^{\circ}$ & Sul/ Sudoeste de Minas & 14 & 1031 \\
$8^{\circ}$ & Vale do Mucuri & 7 & 1003 \\
$9^{\circ}$ & Oeste de Minas & 6 & 455 \\
$10^{\circ}$ & Central Mineira & 4 & 160 \\
$11^{\circ}$ & Zona da Mata & 3 & 63708 \\
\hline \multicolumn{4}{c}{} \\
\hline
\end{tabular}

Fonte: DATALUTA - Banco de Dados da Luta pela Terra, 2010. LAGEA/NERA, 2011.

Por consequência, a RAM que se apresenta de "forma pacifica" sem qualquer forma de luta é quase inexistente e atualmente o Norte de Minas mantém as ocupações como principal forma de criação de assentamentos de Reforma Agrária, como demonstra a tabela 3. Tabela 3: Número de Assentamentos por mesorregiões - (1986 - 2009).

\begin{tabular}{ccc}
\hline CLASS. & MESORREGIÕES & $\mathrm{N}^{\circ}$ DE ASSENTAMENTOS RA \\
\hline $1^{\circ}$ & Norte & 139 \\
$2^{\circ}$ & Triângulo Mineiro/Alto Paranaíba & 59 \\
$3^{\circ}$ & Noroeste & 56 \\
$4^{\circ}$ & Jequitinhonha/Mucuri & 9 \\
$5^{\circ}$ & Rio doce & 4 \\
\hline & TOTAL & 314
\end{tabular}

Fonte: DATALUTA - Banco de Dados da Luta pela Terra, 2010. $\quad$ LAGEA/NERA, 2011. Org. SILVA,D. F., (2011) 


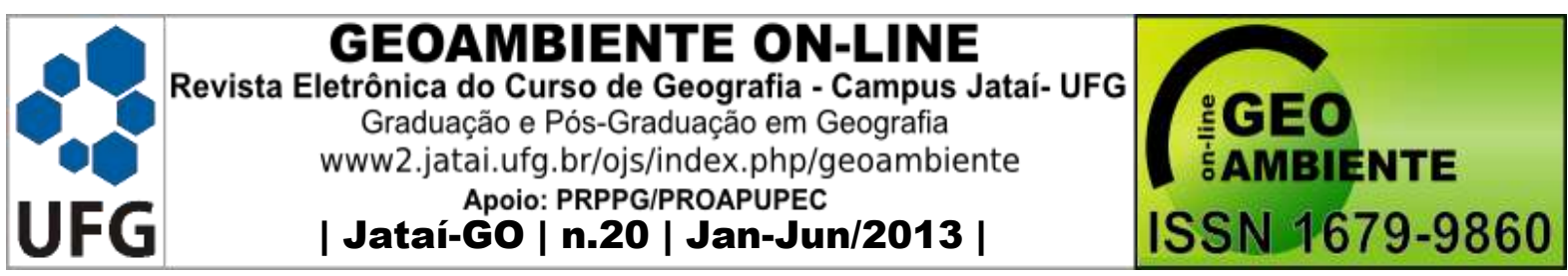

As regiões Sul e a Zona da Mata apresentam processos históricos distintos. Com a decadência do ouro, a economia local teve que se apoiar em outras formas de produção. Dessa forma, no início do século XX a agricultura, que era uma atividade secundária, se sobrepôs às demais atividades. De acordo com Filetto (2001), a produção do café começou a ser inserida nesse contexto, com o tropeiro ou boiadeiro de passagem na região, que ao perceber as boas condições de solo passou a se instalar em pequenas propriedades e a produzir.

Durante a década de 1970, o Programa de Renovação e Revitalização dos Cafezais (PRRC) facilitou a entrada de agricultores de outras regiões do Brasil a se instalarem em Minas. Assim, é possível afirmar que ao contrário da região Norte de Minas, que é marcada por conflitos, na Região Sul e a Zona da Mata, a ocupação foi realizada de forma acordada, pacífica, por isso a implantação dos projetos de Reforma Agrária de Mercado são predominantes na atualidade, fruto de uma trajetória histórica.

A facilidade de circulação de mercadorias, força de trabalho e demanda nas atividades agropecuárias, agroindustriais e urbanas - industriais, fizeram do Triângulo Mineiro/ Alto Paranaíba (Mapa 1) uma das áreas geopolíticas mais importantes do estado.

Mapa 1 - Localização da mesorregião do Triângulo Mineiro/Alto Paranaíba.

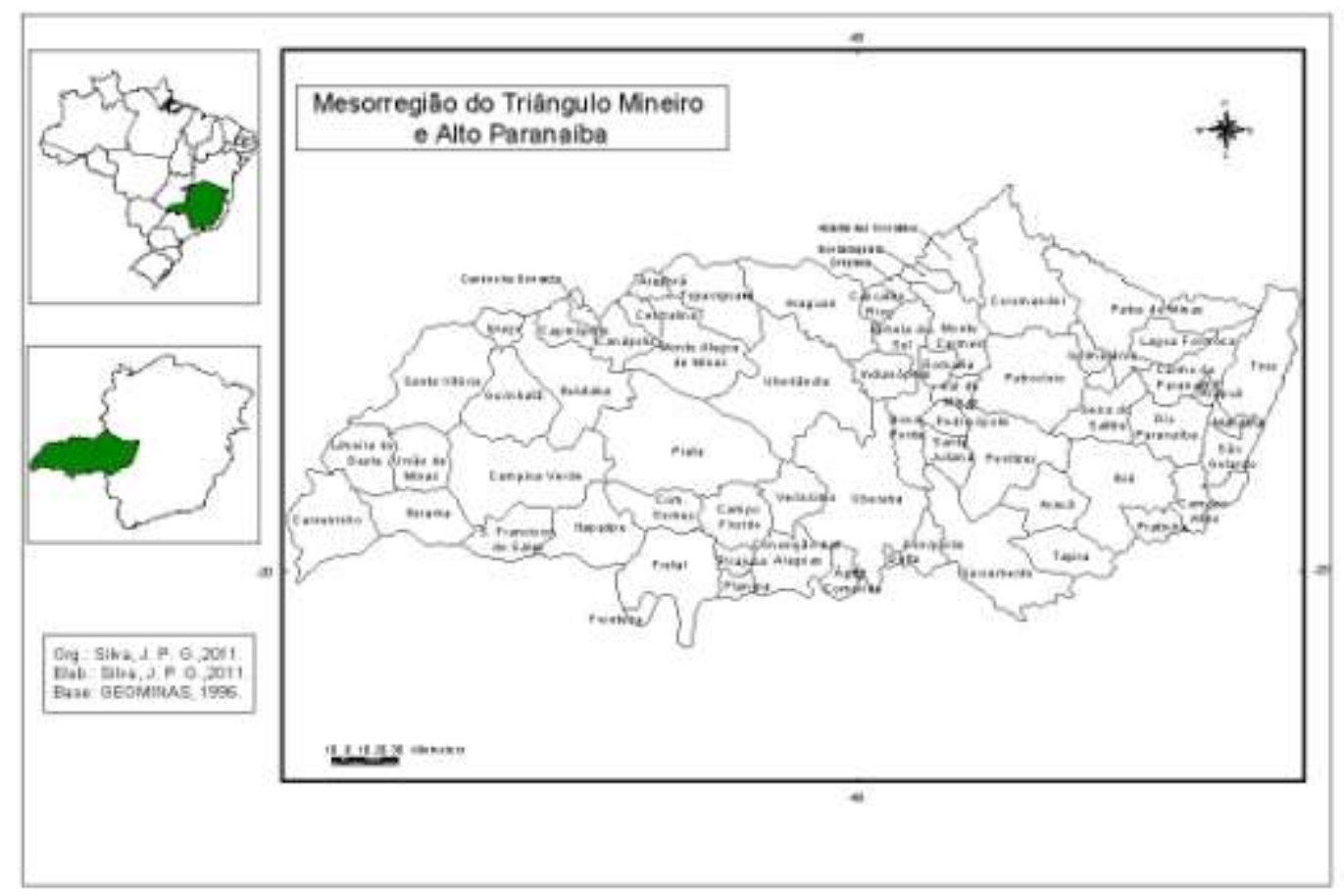

Fonte: Instituto Brasileiro de Geografia e Estatística, IBGE (1994). 


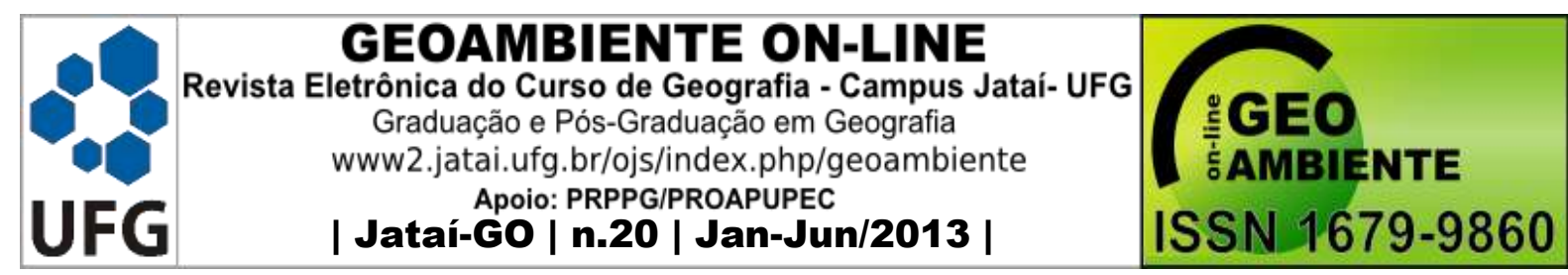

Devido a essa importância, a partir da década de 1970, essa Mesorregião Geográfica passou a receber incentivos do Estado, no intuito de modernizar as estruturas produtivas da agricultura. Com isso, as contradições no campo aumentaram. Tem-se de um lado, o latifúndio que se moderniza e ganha novos objetos geográficos com o ganho de produtividade; e do outro, as comunidades camponesas que até então territorializadas começaram a sofrer um intenso processo de expropriação. Se isso acontece, as migrações campo-cidade também se intensificam.

O campo se torna então sinônimo de negócio, onde o cultivo da terra tem um objetivo: atender a demanda do mercado externo. A terra torna-se mercadoria, o camponês, aquele que ainda persiste no campo, é metamorfoseado em assalariado rural.

Embora essa região seja um cenário constante da luta pela terra, entre o pequeno produtor e os latifundiários, podemos perceber que esta também é palco da Reforma Agrária de Mercado, como demonstra o gráfico 3. Ainda que a reforma agrária convencional tenha maior atuação, os dados são relevantes.

Gráfico 3: Número de Assentamentos de RAM por mesorregião.

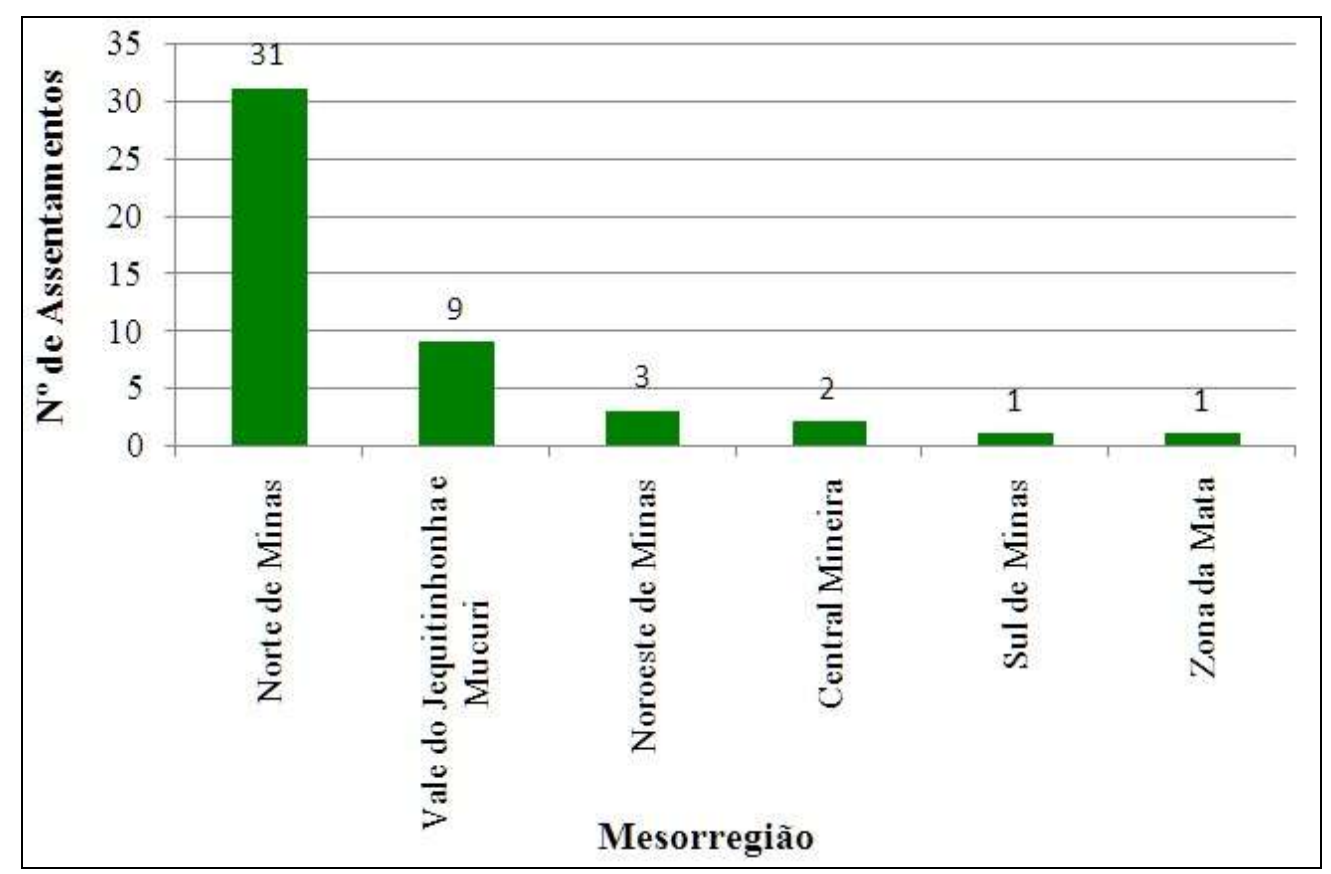

Fonte: pesquisa aos contratos APR/ AFES, 2010.

Org: SILVA, D. F.(2010) 


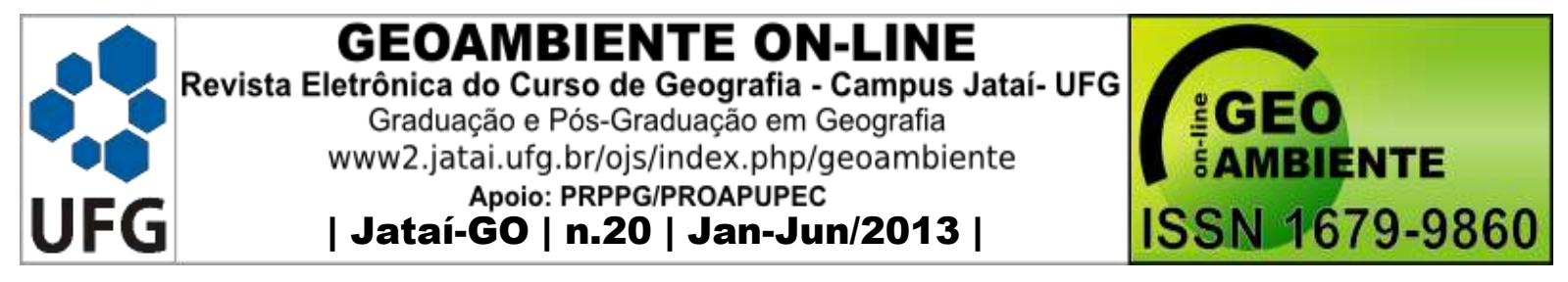

No Triângulo Mineiro/Alto Paranaíba, o projeto Banco da Terra surgiu com o interesse de ruralistas com o apoio do político Odelmo Leão Carneiro. Os grandes produtores assinaram um convênio do "Banco da Terra com a Associação dos Municípios do Vale do Paranaíba, municipalizando, portanto, a implantação da política de Reforma Agrária de Mercado" (RAMOS FILHO, 2009, p.17).

Assim, como nas demais regiões do estado os primeiros projetos implantados tiveram efeitos negativos e "o arranjo elaborado para o Banco da Terra estabeleceu uma condição em que após a implantação (mesmo que parcial) dos empreendimentos, nenhum órgão governamental se responsabilizava pelos empreendimentos" (RAMOS FILHO, 2009, p 18).

Dessa forma, a terra perde o sentido de lugar para trabalho e ganha apenas o valor para negócio. Nesse sentido, nas contradições desse processo ocorrem a precarização das condições de trabalho e de vida dos assentados nesta forma de reforma agrária.

\subsection{A formação do Movimento dos Atingidos pela Reforma Agrária de Mercado} (MARAM)

Com a extinção do projeto Banco da Terra em 2003, as estruturas formadas para a implantação do programa deixaram de prestar assistência às famílias beneficiadas. Coincidentemente, este mesmo ano marcou o encerramento do período de carência das primeiras anuidades dos financiamentos, logo o Banco do Brasil emitiu cartas de cobrança solicitando o pagamento de toda a dívida acumulada. O endividamento de diversas famílias somou-se a outros problemas, como a fragilidade das associações, casos de corrupção, dificuldade e/ ou inacessibilidade aos créditos agrícolas e a incompletude na implantação de boa parte dos empreendimentos. Além disso, as questões referentes aos empreendimentos passam a ser tratadas apenas na dimensão financeira junto aos bancos que lhes concederam o financiamento, fato que desesperou as famílias (RAMOS FILHO, 2010, p.81).

Diante deste processo as famílias mutuárias, que já dispõem de pouca ou quase nenhuma informação e conhecimento sobre direitos, ficam abandonadas frente à inexistência de órgãos que se responsabilizem e/ou contribuíam com a solução dos problemas referentes ao endividamento principalmente, mas também à conservação dos empreendimentos, garantia de direitos sociais, assistência técnica e extensão rural, transporte, acesso a água e eletricidade, melhoria das condições de moradia 


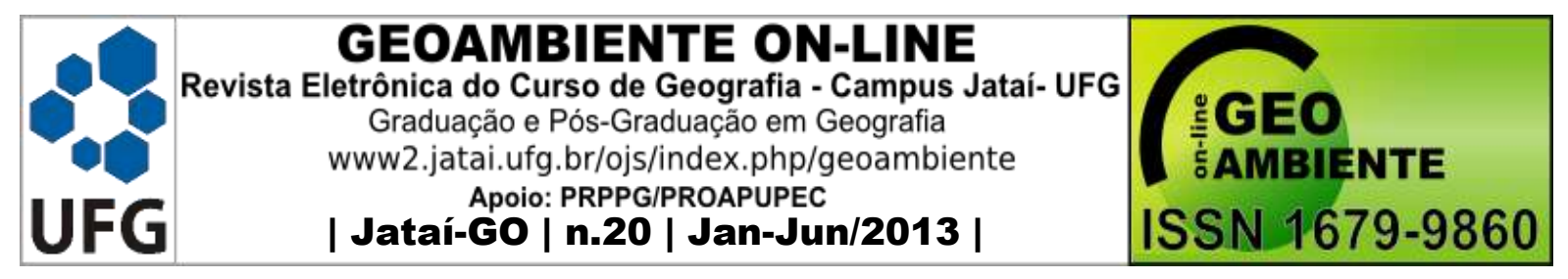

(RAMOS FILHO, 2010, p.81).

A experiência concreta das famílias frente ao ideário das políticas de RAM tem comprometido não apenas os programas de crédito, como o Banco da Terra, mas também a sua própria sobrevivência. Diante da necessidade de encontrar soluções para estes desencontros, mesmo com a baixa organicidade, as associações de mutuários do Banco da Terra e entidades como a Animação da Pastoral Rural - APR, entidade ligada a CPT, e a Ação Franciscana de Ecologia e Solidariedade - AFES, formaram em assembléia no dia 11 de novembro de 2005, o Movimento dos Atingidos pela Reforma Agrária de Mercado MARAM, na cidade de Ituiutaba - no Triângulo Mineiro/Alto Paranaíba.

Foi a partir do dimensionamento de espaços interativos e comunicativos que os
mutuários do Banco da Terra do Triângulo Mineiro/Alto Paranaíba, decidiram pela
criação do MARAM como forma de organização política para exercer a devida
pressão junto aos governos municipais, estadual e federal com vistas a encontrar
condições de realizar a negociação da dívida e recuperação da capacidade de
aquisição de créditos agrícolas, com vistas a recuperar a capacidade produtiva dos
empreendimentos falidos. Reivindicam, ainda, os mesmo direitos e acessos às
políticas públicas que os beneficiários da reforma agrária (RAMOS FILHO, 2010,
p.208).

O longo do período, o MARAM tem alcançado algumas conquistas, como a renegociação das dívidas e a individualização (discriminação) dos lotes, uma vez que o empreendimento possui o registro em nome da associação e assim, particularizando como único movimento de luta na problemática da Reforma Agrária de Mercado no Brasil. A atuação do MARAM tem se concentrado no Triângulo Mineiro/ Alto Paranaíba, 107 empreendimentos desta mesorregião 88 estão filiados ao movimento e não há nenhum registro de outra associação de mesorregião diferente. Sendo assim, o movimento se esforça para conseguir a adesão de mutuários de outras regiões do estado, embora, nestas áreas, as condições de desterritorialização sejam mais expressas no abandono dos lotes e a completa alienação dos mutuários, fato que desestabiliza esta luta.

Desta forma, o movimento ainda se esforça para conseguir reverter as dificuldades sociais enfrentadas pelos agricultores, uma vez que ao contrário dos movimentos sociais de luta pela terra que possuem uma estrutura política mais consolidada, as associações mutuarias 


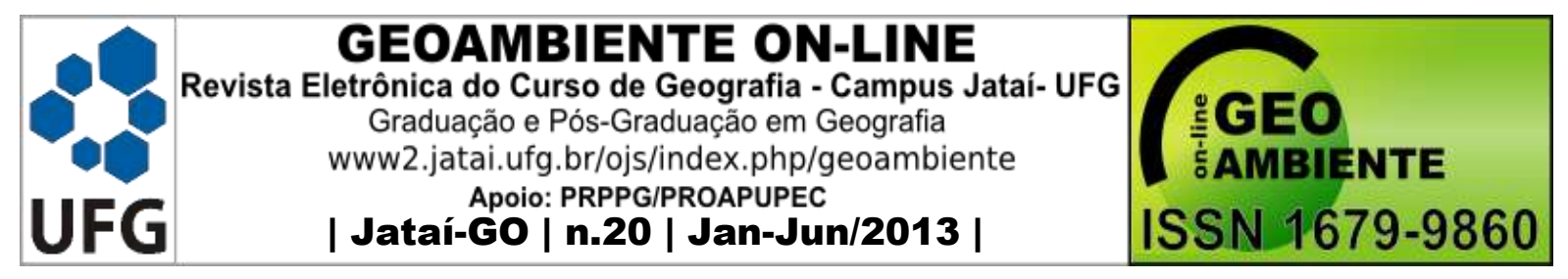

da RAM se organizaram apenas no momento da compra da terra, o que dificulta uma mobilização social mais efetiva.

\section{Considerações finais}

- Diante do acirramento das tensões no campo na década de 1990, o Banco Mundial liberou uma série de ajustes a fim de aprofundar a redução do papel do Estado por meio de medidas gerenciais de administração pública, impondo o mercado neoliberal aos países subdesenvolvidos. Neste contexto, o Brasil se insere nessa nova realidade, implantando o programa Cédula da Terra.

- O sonho de se obter a primeira terra por meio dos projetos da Reforma Agrária de Mercado tem demonstrado aspectos negativos como a aquisição de propriedades com preços elevados, isoladas geograficamente ou que não atendem as necessidades prioritárias, como o acesso a água potável. Contudo, o enfraquecimento das mobilizações sociais e a dificuldade de permanência das associações mutuárias, tem sido o maior desafio para a criação e permanência destas famílias.

- No Triângulo Mineiro/Alto Paranaíba, mesorregião conhecida por intensos conflitos por terra, os ruralistas articularam a implantação do projeto Banco da Terra para conter as conquistas dos movimentos sociais. Contudo, diante das dificuldades de permanência nos empreendimentos, as famílias atingidas formaram o primeiro movimento de luta contra a Reforma Agrária de Mercado, o MARAM.

- Em geral, os mutuários do Banco da Terra não possuem as instruções necessárias para reivindicar seus direitos e o MARAM tem articulado com as famílias beneficiadas renegociações das dívidas, assim como ações para a superação dos problemas internos nos empreendimentos. Nesse período, o movimento ainda se esforça para conseguir adesão das associações dos agricultores de outras mesorregiões do estado, uma vez que elas se organizam apenas no momento da compra e ao contrário dos movimentos sociais de luta pela terra, o que dificulta uma mobilização mais efetiva. 


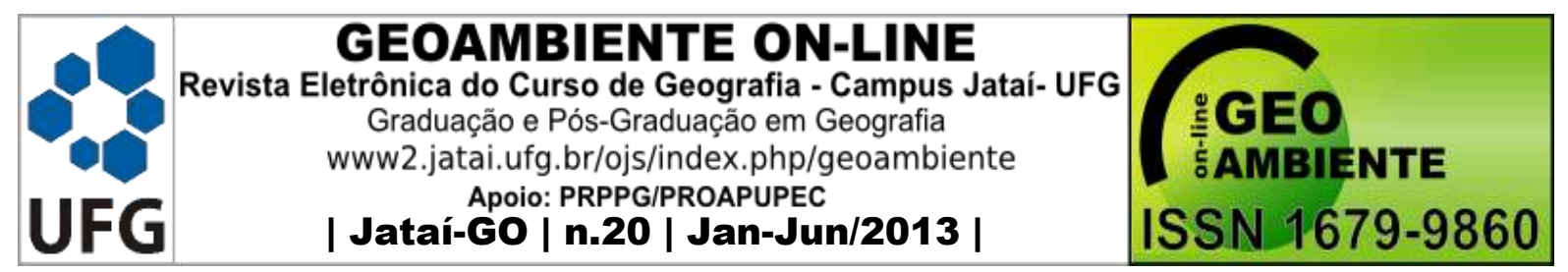

${ }^{1}$ Criado no início da década de 1990, o PRONAF tem como objetivo financiar projetos individuais ou coletivos, que gerem renda aos agricultores familiares e assentados da reforma agrária (Ministério do Desenvolvimento Agrário, 2010).

\section{Referências}

BRASIL. Reforma agrária: um compromisso de todos. Brasília: Presidência da República/SECOM, $1997 . \quad$ Disponível em: < http://www.planalto.gov.br/publi_04/COLECAO/REFAGR.HTM> Acesso em: 28 ago. 2011. CARDOSO, F. H. Mãos à obra Brasil: proposta de governo. Rio de Janeiro: Biblioteca Virtual de Ciências Humanas, 2008.

FERNANDES, B. M. Questão Agrária, Pesquisa e MST. São Paulo, Cortez, 2001.

FILETTO, F; ALENCAR, E. Introdução e expansão do café na região sul de Minas Gerais. Organizações Rurais e agroindustriais, Lavras, v.3, n1, p. 01-10, janeiro/junho/2001. Disponível em : <http://www.dae.ufla.br/revista/>. Acesso em 08 de fev 2011.

GRAZIANO DA SILVA, Para entender o Plano Nacional de Reforma Agrária. São Paulo: editora Brasiliense, 1985.

GOMES, R. M. Terra, exclusão e resistência uma reflexão sobre a realidade agrária brasileira. 2002. 96 f. Monografia (Graduação em Ciências Sociais) Faculdade de Filosofia, Artes e Ciências Sociais da Universidade Federal de Uberlândia, Uberlândia, 2002.

INSTITUTO BRASILEIRO DE GEOGRAFIA E ESTATÍSTICA. Mesorregiões Mineiras. Disponível em: < http://www.ibge.gov.br/home/> . Acesso: 30 out 2011.

INSTITUTO NACIONAL DE COLONIZAÇÃO E REFORMA AGRÁRIA - INCRA. Titulação de Assentamentos. Disponível em: $<$ http://www.incra.gov.br/portal/index.php?option=com_content $\&$ view=category\&layout=blo g\&id=286\&Itemid=299 > Acesso em: 09 abr 2011 


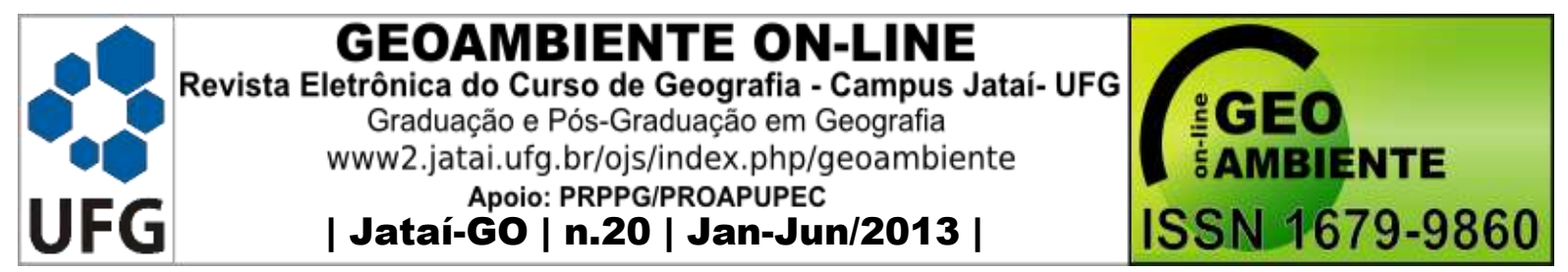

MARTINS, J. S. A reforma agrária no segundo mandato de Fernando Henrique Cardoso. Tempo Social, Revista de Sociologia - São Paulo, v. 15, n.2, p. 141-175, nov. 2003. Disponível em: < http://www.scielo.br/scielo.php?script=sci_arttext\&pid=S0103$20702003000200006>$ Acesso em: 01 out 2011.

OLIVEIRA, A. U. A "não Reforma Agrária" do MDA/INCRA no Governo Lula. Trabalho apresentado na reunião paralela realizada pela Via Campesina durante a Conferência Internacional sobre Reforma Agrária e Desenvolvimento Rural - CIRADR-FAO, Porto Alegre-RS, 2006.

PAUlinO, E. T. Politicas territoriais e questão agrária: da teoria à intervenção. In: SAQUET, M. A. SANTOS, R. A. (Org.). Geografia agrária, território e desenvolvimento. São Paulo: Expressão Popular, 2010. p.107-130.

RAMOS FILHO, E. S. De pobre e sem-terra à pobre com-terra e sem sossego: territorialização e territorialidades da reforma agrária de mercado em Sergipe (2001-2004). In: VI Encontro Nacional da Anpege. Fortaleza/CE. Anais..., 2005.

Da prisão da dívida ao território da política: reforma agrária de mercado e o combate a pobreza rural. Os casos da CONTAG, MST e MARAM. 2009. (Apresentação de Trabalho/Seminário).

Movimentos socioterritoriais, a reforma agrária de mercado do banco mundial e o combate a pobreza rural: os casos do MST, CONTAG e MARAM. Subordinação e resistência camponesa. 2010. 221 f. Relatório (Pós - doutorado em Geografia). Instituto de Geografia, Universidade Federal de Uberlândia, Uberlândia, 2010.

RANIERI, S. B. L. Retrospecto da Reforma Agrária no mundo e no Brasil. In: SPAROVEK, G. A qualidade dos assentamentos de Reforma Agrária brasileira. São Paulo: Páginas \& Letras, 2003.

ROCHA. H.F. Análise e mapeamento dos tipos de assentamentos no Brasil: compreender a diversidade e a atualidade da reforma agrária brasileira: estudo dos assentamentos da região centrosul. 2008. 72 f. Relatório (Iniciação Científica em Geografia). Universidade Estadual Paulista, Campus Presidente Prudente, Presidente Prudente, 2008. 


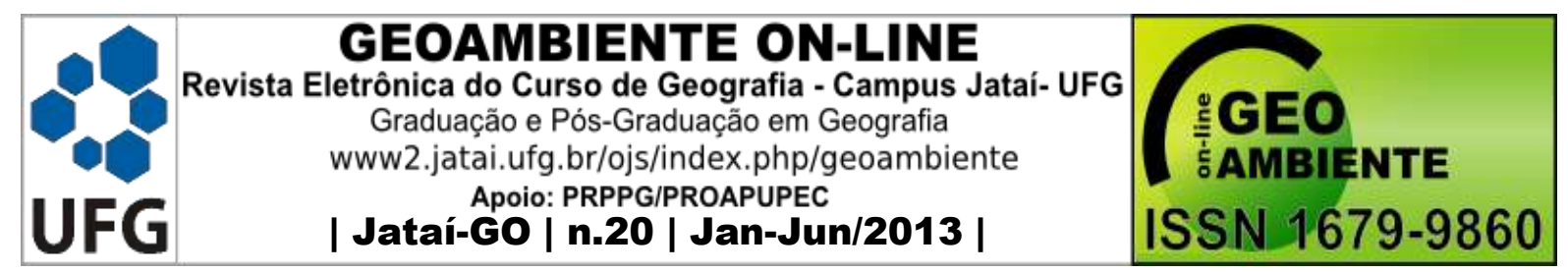

SAUER, Sérgio.; BARROS, Flavia.; SCHWARTZMAN, S. (Orgs.). Os impactos negativos da reforma agrária de mercado do Banco Mundial. $1^{\mathrm{a}}$ ed. Brasília: Rede Brasil e Environment Defense, 2003. v. 1.

STÉDILE, J. P. (Org.). A questão agrária no Brasil. São Paulo: Expressão Popular, 2005. 3 vol.

TEIXEIRA, G. Fatos e mitos da política agrícola do governo FHC. São Paulo, 1997. 